\title{
THE GEOLOGY OF CARBONACEOUS DEPOSITS (CARBONIFEROUS) OF THE SOUTH URALS (FEDOROVSKAYA SEQUENCE, SUKHARYSH SYNCLINE)
}

\author{
A.V. Snachev \\ Institute of Geology, Ufa Federal Research Center, Russian Academy of Sciences, \\ Ufa, 450077 Russia
}

\begin{abstract}
The geological structure of coal formations of the Sukharysh syncline, which is located in the Kopeysk-Bredy subzone of the Alapaevsk-Adamovka structural-formational zone, was studied. The focus was specifically on the deposits of the Fedorovskaya sequence $\left(\mathrm{C}_{2} \mathrm{fd}\right)$ with outcrops in the sections along the Uvelka River and in few roadside pits. The width of the sequence is about $1000 \mathrm{~m}$. The Middle Carboniferous (Bashkirian) age of the deposits was reliably dated based on the fossil faunal finds. It was shown that shales and aleurolites, which are widespread in the limestones of the Fedorovskaya sequence, belong to the low-carbon type and fall into the field of the siliceous-carbonate unit. The carbonaceous matter is developed in the form of scattered impurities, concentrated in the ultrafine veinlets and laminas, and corresponds to higher kerites subjected to catagenesis and the early stage of green shales facies. The organic carbon content is up to $20 \%$, and, thus, the rock appears to be opaque. Sedimentation process took place in the isolated local shallow-water depressions under the geodynamic conditions of collision. The terrigenous material was formed as a result of the destruction of the underlying rocks of the major and average element composition of the Berezinskaya sequence. The maturity of the deposits consistently increases from the Tugundinskaya to Fedorovskaya sequences.
\end{abstract}

Keywords: South Urals, Sykharysh syncline, Fedorovskaya sequence, stratigraphy, paleogeography, carbonaceous shales, black shales, TOC, Carboniferous

\section{Introduction}

In the world's largest gold deposits, carbonaceous shales often become the oregenerating and -hosting strata and, therefore, hold promise for future research. As for the South Urals, these shales have remained overlooked here for many years, despite their widespread distribution along the structural-formational zones, the widest age inter$\mathrm{val}$, and the ability to form in various paleogeographic conditions. Earlier exploration campaigns have found that the Carboniferous carbonaceous shales of the East Urals megazone host a number of commercial gold deposits (Kumakskoe, Svetlinskoe, Kamenskoe, Tetechnoe, etc.), thereby fostering greater research interest in this region [1-5].

This paper is based on the materials obtained from the study of carbonaceous shales of the Fedorovskaya sequence as part of the geological survey [6] and the thematic investigations of the Sykharysh syncline. 


\section{Materials and Methods}

Thermogravimetric analysis of the carbonaceous rock samples was performed using a Q-1500 derivatograph (analyst T.I. Chernikova, Institute of Geology, Ufa Federal Research Center, Russian Academy of Sciences). The samples were heated in air at a temperature of $20-1000{ }^{\circ} \mathrm{C}$ and at a rate of $10{ }^{\circ} \mathrm{C} / \mathrm{min}$. Only samples of the least silicified and sulphidized rocks outside the zones of intrusive exocontacts and intensive tectonic reworking were used for analysis to exclude their possible influence and determine the degree of regional metamorphism. Silicate analysis was carried out by the standard methods (analyst S.A. Yagudina, Institute of Geology, Ufa Federal Research Center, Russian Academy of Sciences).

\section{Geological Structure of the Sukharysh Syncline}

The Sukharysh syncline is located in the Kopeysk-Bredy subzone of the Alapaevsk-Adamovka structural-formational zone. It borders on the Kosobrodsk anticline to the south, being bounded by the Alapaevsk-Chelyabinsk deep fault to the east (Fig. 1).
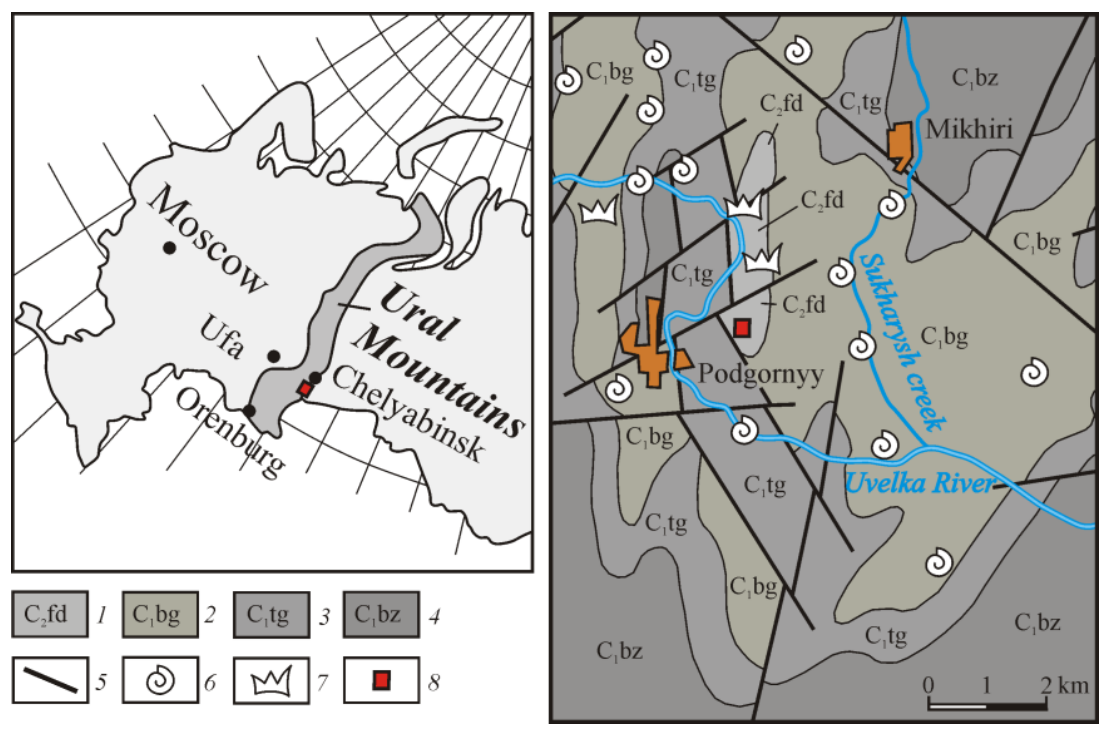

Fig. 1. Geological map of the Sukharysh syncline (according to B.A. Puzhakov [6], simplified by the author). Legend: 1 - Fedorovskaya sequence (organogenic-detrital pelitomorphic gray and dark-gray limestones, interbeds of carbonaceous-clayey shales), 2 - Birgil'dinskaya sequence (sandstones, gravelstones, carbonaceous-clayey shales, limestines), 3 - Tugundinskaya sequence (limestones, sandstones, aleurolites, often carbonaceous), 4 - Berezinovskaya sequence (lavas, lava breccias, trachybasalt tuffs interbedded with siliceous tuffites, clayey-carbonaceoussiliceous shales), 5 - faults, 6 - finds of foraminifers, 7 - finds of brachiopods, 8 - location of the studied section

The limbs of the structure are composed of the Tournaisian-Lower Visean volcanogenic rocks of the Berezinovskaya sequence $\left(\mathrm{C}_{1} \mathrm{bz}\right)$. Its deposits have unconformable contacts with the underlying units and are dominated by lavas, lava breccias, as well as trachybasalt, basalt, and andesite tuffs interbedded with sericite-chlorite-plagioclase- 
quartz shales. The total width of the sequence is $500-1500 \mathrm{~m}$. The Tugundinskaya sequence $\left(\mathrm{C}_{1} \mathrm{tg}\right)$ rocks, mostly limestones $(75 \%)$, overlie unconformably. In the deeper part of the section, arkose and polymictic sandstones, aleurolites prevail, whereas conglomerates and gravelstones are less common. The conglomerates often include clasts originating from volcanites of the underlying Berezinovskaya sequence. The Early Carboniferous (Visean) age of the Tugundinskaya sequence is reliably dated based on numerous foraminifers in its units. The sequence is up to $1800 \mathrm{~m}$ wide. The section shows a consistent thickening through the Birgil'dinskaya sequence $\left(\mathrm{C}_{1} \mathrm{bg}\right)$ dominated by limestones that are interbedded with shales (carbonaceous-clayey, clayey, and calcareous-clayey), aleurolites, and sandstones. The limestones are organogenic, pelitomorphic crinoidal-detrital, fine- and close-grained, and pelleted. The faunal finds confirm the Early Carboniferous (Late Visean - Serpukhovian) age of the sequence. Its width ranges up to $1000 \mathrm{~m} \mathrm{[6].}$

\section{Description of Carbonaceous Shales in the Fedorovskaya Sequence}

The Fedorovskaya sequence $\left(\mathbf{C}_{2} \mathbf{f d}\right)$ was discovered during the geological survey of the Chelyabinsk area, a northward neighboring region, in 1995-1999 and named after the village of Fedorovka. Its deposits occur unconformably on the Birgil'dinskaya sequence and are represented by organogenic-detrital pelitomorphic gray and dark-gray limestones interbedded with carbonaceous-clayey shales and carbonaceous argillites. The sequence outcrops in the sections along the Uvelka River and in few roadside pits (Fig. 2). The width of the sequence is about $1000 \mathrm{~m}$.

The following rich faunal assemblages pinpoint the Middle Carboniferous age (Bashkirian) for the sequence: brachiopods - Schisophoria resupinata (Martin), Antiguatonia nindi (Muir-Wood), A. cf. subcata (Sow.), Tirinifer cf. pseudolineatus (Hall.), Buxtonia ex gr. juresanensis (Tsch.) (identified by M.V. Postoyalko); foraminifers Bradyina cribrostomata Raus. et Reitl., Eostaffella pseudostruvei (Raus. et Reitl.), Globivalvulina cf. moderata Reitl., Asteroarchaediscus pustules (Grosd. et Leb.), Pseudoendothyra luminosa (Durk.), Profusulinella ex gr. parva (Lee et Chen), Tolypammina sp., Plectostaffella sp., Ozavainella sp., Millerella umbilicata Kir. (identified by M.V. Postoyalko, R.M. Ivanova, B.I. Chuvashov); conodonts - Declinognathoidus noduliferus (Ellison et Graves), D. lateralis (Higgins et Douckaert), D. noduliferus inaegualis (Higgins), Paragnathodus ericiformis (Clarke) (identified by V.N. Pazukhin) [6].

Carbonaceous shales and aleurolites of the Fedorovskaya sequence are mostly gray or dark gray in color. Their stratified texture is determined by the presence of interbedded radiolarites and filamentous carbonaceous matter in the ground microcrystalline siliceous mass (Fig. 3, $a, b$ ). The clay matter (hydromica) is found in small proportions and forms striated inclusions and short laminas. The rock contains thin $(0.5-$ $2.0 \mathrm{~mm}$ ) radiolarite interbeds with the large detrital accumulations (up to 60\%) of radiolarians, sponge spicules (?), and shell fragments, up to $0.1 \mathrm{~mm}$ in size (Fig. 3, $c, d$ ). Such interlayers are generally porous and characterized by a much lower content of the carbonaceous matter, which is present as a scattered impurity. Phosphorized fragments of dirty brownish ichthyodetritus (?) occur rarely. They are thinly laminated, with the admixed carbonaceous matter (Fig. 3,e). Such fragments often have irregular shape, jagged edges, and sizes of 0.5 to $2.5 \mathrm{~mm}$. 


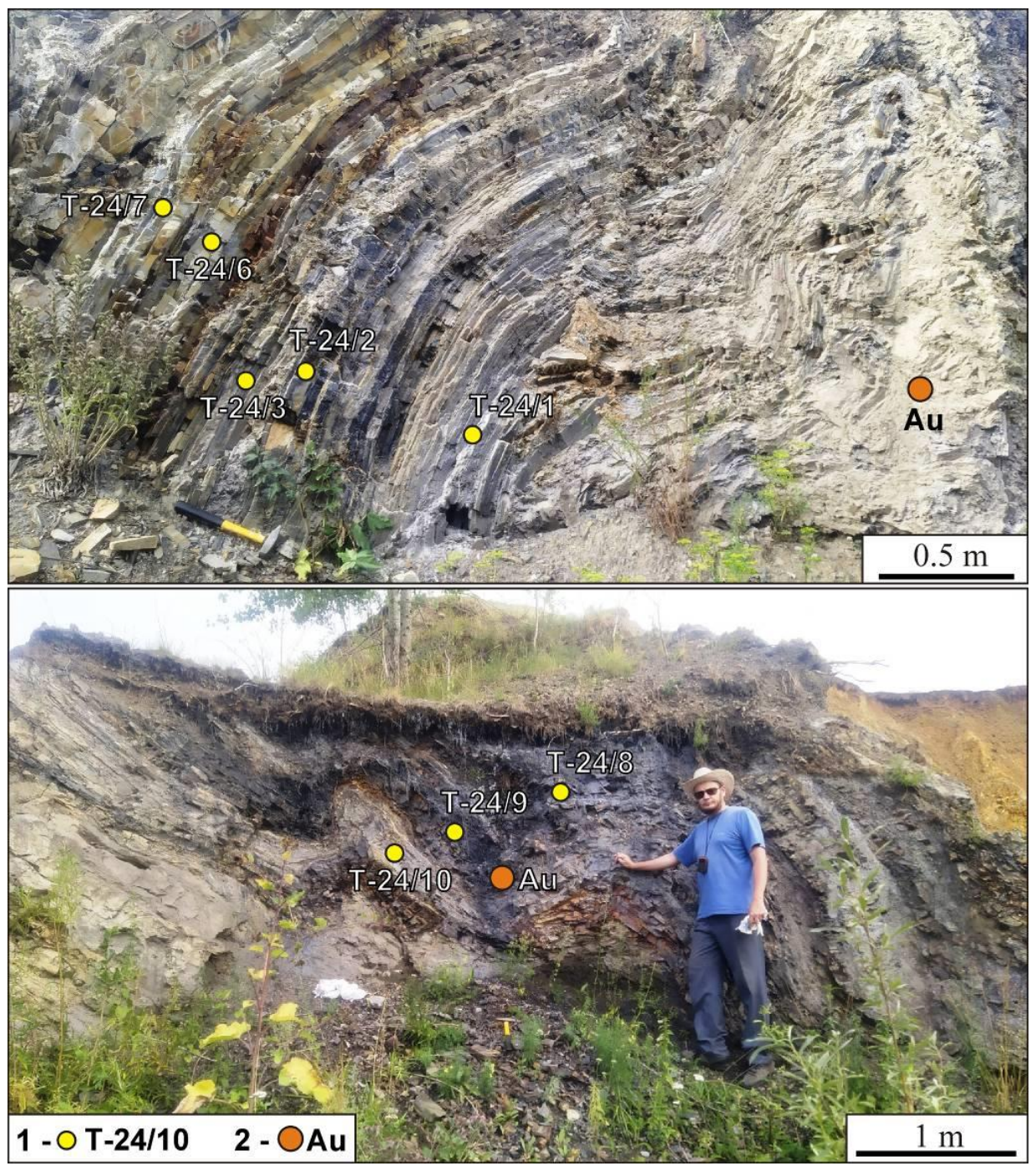

Fig. 2. Photos showing the sections of carbonaceous shales of the Fedorovskaya sequence. Note: 1 - flagged sample positions for silicate and thermal analyses, 2 - sampling points where gold specks were registered

The accessory minerals are short-prismatic idiomorphic corroded glauconite crystals (up to $0.1 \mathrm{~mm}$ ), rarely oxidized pyrite crystals of cubic habit (up to $0.2 \mathrm{~mm}$ ). Single grains of amphibole, garnet, staurolite, ilmenite, and chromite were recorded in the black sand.

The brown carbonaceous matter is developed in the form of scattered impurities and concentrated as ultrafine veinlets and laminas. In certain areas, its content amounts to $20 \%$, and the rock appears to be opaque. The cavities of organogenic detritus are filled with bitumen greases (Fig. 3, f). The thermal analysis showed that gray shales and aleurolites from the Fedorovskaya sequence have low contents of organic carbon (up to $0.5 \%$ ). However, the section still displays dark-gray or black interbeds (up to $0.5 \mathrm{~m}$ thick) with the $\mathrm{C}_{\mathrm{TOC}}$ level up to $2.8 \%$ (Fig. 2, 4; Table 1). This indicates that the deposits belong to the low-carbon type, which is widespread in the South Urals [7, 8]. 

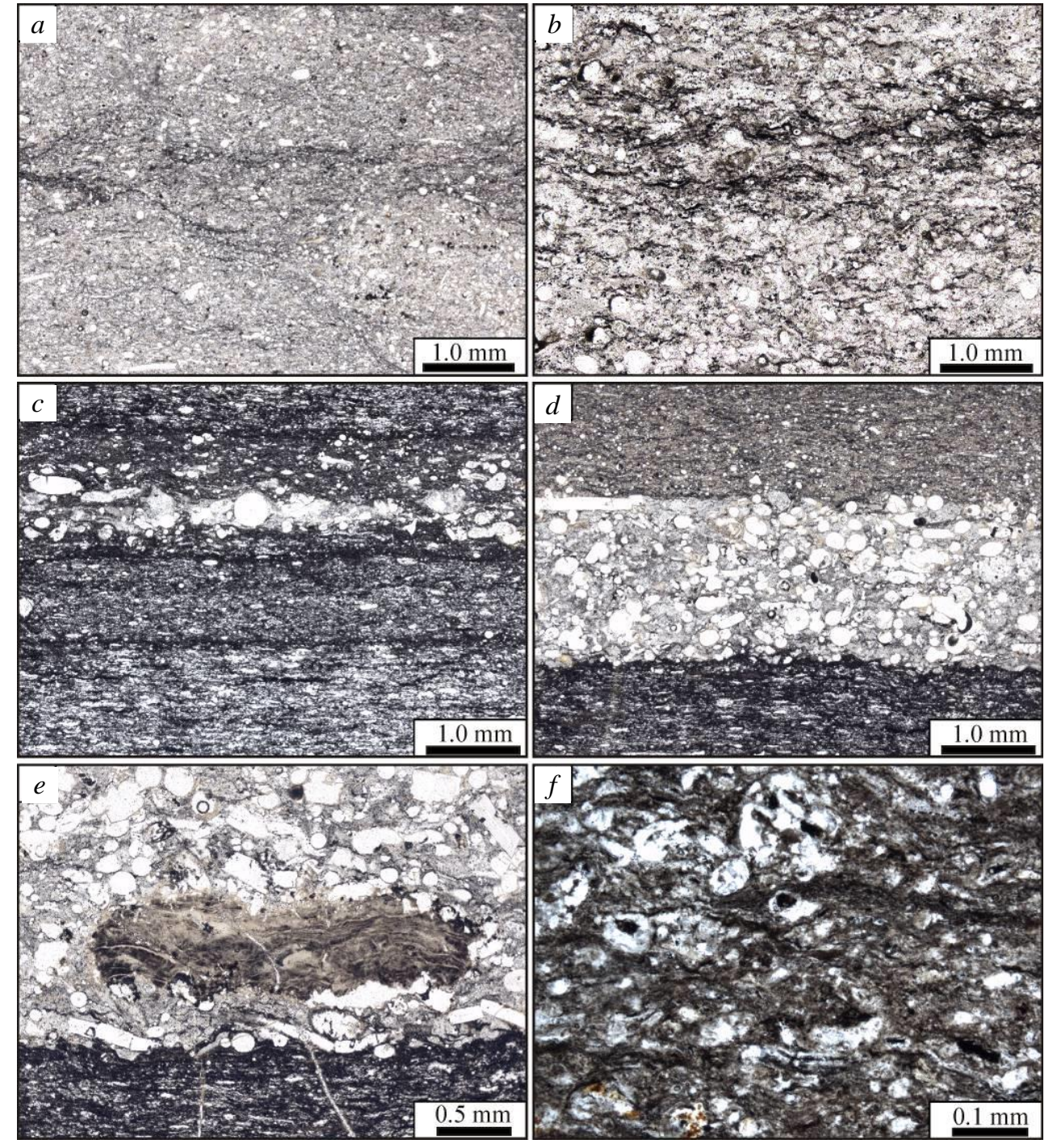

Fig. 3. Photos of the microsections of carbonaceous shales from the Fedorovskaya sequence. Note: $a$ - organogenic structure of carbonaceous aleurolite (microsection T-24-10); $b$ - interbed with the high content of carbonaceous matter in the detritus of radiolarians (microsection T-24-10); $c, d$-various concentrations of the carbonaceous matter in the aleurolite and radiolarite interbeds (microsection T-24-3); $e$ - fragment of phosphorized ichthyodetritus (?) (microsection T-24-3); $f$-cavities in organogenic detritus filled with dark-brown bitumen greases (microsection T-24-9). All photos in parallel nicols

The exothermic reaction of carbon with oxygen in the shales starts at low temperatures, from $490{ }^{\circ} \mathrm{C}\left(550^{\circ} \mathrm{C}\right.$ on average), thereby suggesting that the level of carbon metamorphism is low and corresponds to higher kerites subjected to catagenesis and the early stage of green shales facies $[9,10]$. 
$a$
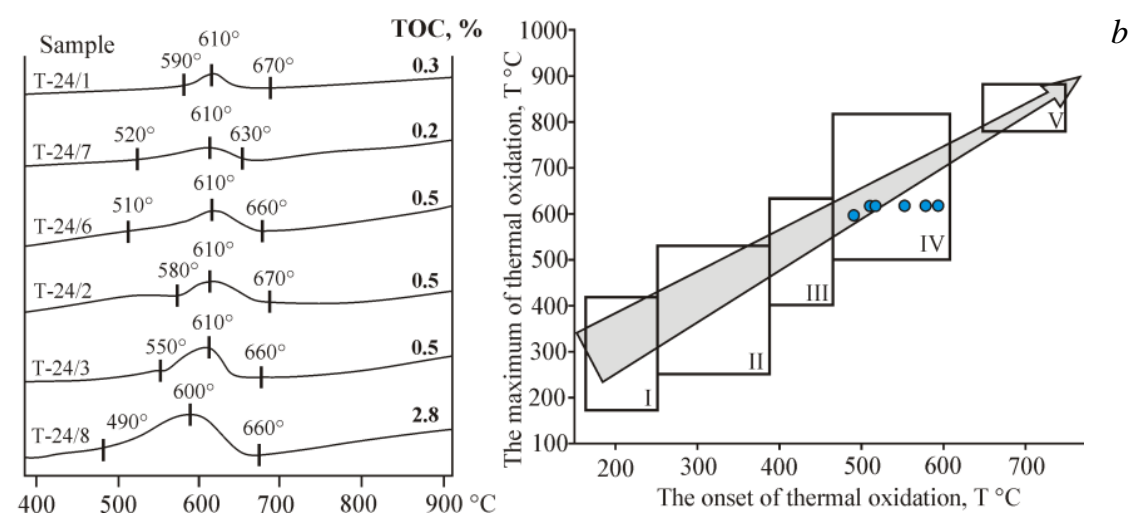

Fig. 4. Characteristic thermograms $(a)$ and positions of the analysis points on the thermal resistance diagram $(b)$ for the carbonaceous deposits of the Sukharysh syncline. Note: burn-off stages according to V.I. Silaev et al. [10]: I - recent plants, organic matter in unmetamorphosed sedimentary rocks, coprolites; II - asphalts, lower kerites; III - asphaltites, kerites; IV - higher kerites, anthraxolites, shungites; V - graphite, carbonado

Table 1

Results of the thermal analysis of carbonaceous shales of the Fedorovskaya sequence

\begin{tabular}{|c|c|c|c|}
\hline Sample no. & $\begin{array}{c}\text { Onset } \\
\text { of effect }\left({ }^{\circ} \mathrm{C}\right)\end{array}$ & $\begin{array}{c}\text { Maximum } \\
\text { effect }\left({ }^{\circ} \mathrm{C}\right)\end{array}$ & TOC $(\%)$ \\
\hline $\mathrm{T}-24 / 1$ & 590 & 610 & 0.3 \\
\hline $\mathrm{T}-24 / 2$ & 580 & 610 & 0.5 \\
\hline $\mathrm{T}-24 / 3$ & 550 & 610 & 0.5 \\
\hline $\mathrm{T}-24 / 6$ & 510 & 610 & 0.5 \\
\hline $\mathrm{T}-24 / 7$ & 520 & 610 & 0.2 \\
\hline $\mathrm{T}-24 / 8$ & 490 & 590 & 2.8 \\
\hline
\end{tabular}

\section{Petrogeochemistry of the Sukharysh Syncline Rocks}

Carbonaceous deposits have proved their worth as reliable sources for reconstructing the sedimentation conditions. The chemical composition of sedimentary rocks can reveal a lot about the original source of clastic elements. The petrogeochemical features of carbonaceous shales and aleurolites in the Tugundinskaya $\left(\mathrm{C}_{1} \mathrm{tg}\right)$, Birgil'dinskaya $\left(\mathrm{C}_{1} \mathrm{bg}\right)$, and Fedorovskaya $\left(\mathrm{C}_{2} \mathrm{fd}\right)$ sequences were studied using the standard classification diagrams (Table 2, Fig. 5).

On the A-S-C diagram [11] (Fig. 5, a), carbonaceous shales and aleurolites of the Tugundinskaya sequence fall into the field of terrigenous-carbonate unit, while those of the Fedorovskaya and Birgil'dinskaya sequences into the siliceous-carbonate unit. The increased $\mathrm{S}$ parameter, which is inversely proportional to the amount of terrigenous impurities in the sediment, indicates that the sedimentation process shifts to lower depths or that there are isolated local depressions, where the deposits of the Fedorovskaya sequence accumulated during the Middle Carboniferous.

It is evident from the distribution of the imaging points showing the composition of carbonaceous deposits of the Sukharysh syncline on the DF1-DF2 and F1-F2 diagrams (Fig. 5, b, c) that these rocks settled under the conditions of collision. The sources of terrigenous material supply must have been eroded underlying rocks of the major and average element composition of the Berezinovskaya sequence $\left(\mathrm{C}_{1} \mathrm{bz}\right)$. 
Table 2

Results of the chemical analysis of carbonaceous shales of the Fedorovskaya sequence

\begin{tabular}{|l|c|c|c|c|c|c|c|}
\hline \multicolumn{1}{|c|}{ Sample no. } & $\mathrm{T}-24 / 1$ & $\mathrm{~T}-24 / 2$ & $\mathrm{~T}-24 / 3$ & $\mathrm{~T}-24 / 6$ & $\mathrm{~T}-24 / 7$ & $\mathrm{~T}-24 / 8$ & $\mathrm{~T}-24 / 10$ \\
\hline $\mathrm{SiO}_{2}$ & 90.00 & 92.00 & 93.00 & 96.00 & 95.00 & 80.00 & 92.00 \\
\hline $\mathrm{TiO}_{2}$ & 0.10 & 0.10 & 0.10 & 0.10 & 0.10 & 0.25 & 0.20 \\
\hline $\mathrm{Al}_{2} \mathrm{O}_{3}$ & 6.40 & 0.90 & 3.60 & 0.90 & 0.90 & 7.82 & 3.00 \\
\hline $\mathrm{Fe}_{2} \mathrm{O}_{3}$ & 0.70 & 0.60 & 1.00 & 0.70 & 0.32 & 0.70 & 0.40 \\
\hline $\mathrm{MnO}$ & 0.06 & 0.09 & 0.05 & 0.15 & 0.14 & 0.03 & 0.05 \\
\hline $\mathrm{MgO}$ & 1.00 & 3.00 & 1.00 & 0.20 & 1.00 & 2.00 & 2.00 \\
\hline $\mathrm{CaO}$ & 0.30 & 0.50 & 0.10 & 0.10 & 0.10 & 0.10 & 0.10 \\
\hline $\mathrm{Na}_{2} \mathrm{O}$ & 0.20 & 0.25 & 0.30 & 0.30 & 0.50 & 0.50 & 0.54 \\
\hline $\mathrm{K}_{2} \mathrm{O}$ & 0.20 & 0.10 & 0.20 & 0.20 & 0.20 & 1.00 & 0.12 \\
\hline $\mathrm{P}_{2} \mathrm{O}_{5}$ & 0.01 & 0.01 & 0.01 & 0.01 & 0.01 & 0.01 & 0.01 \\
\hline Other impurities & 1.40 & 2.70 & 1.00 & 2.00 & 2.00 & 7.50 & 2.00 \\
\hline Total & 100.31 & 100.16 & 100.31 & 100.51 & 100.13 & 99.88 & 100.37 \\
\hline
\end{tabular}
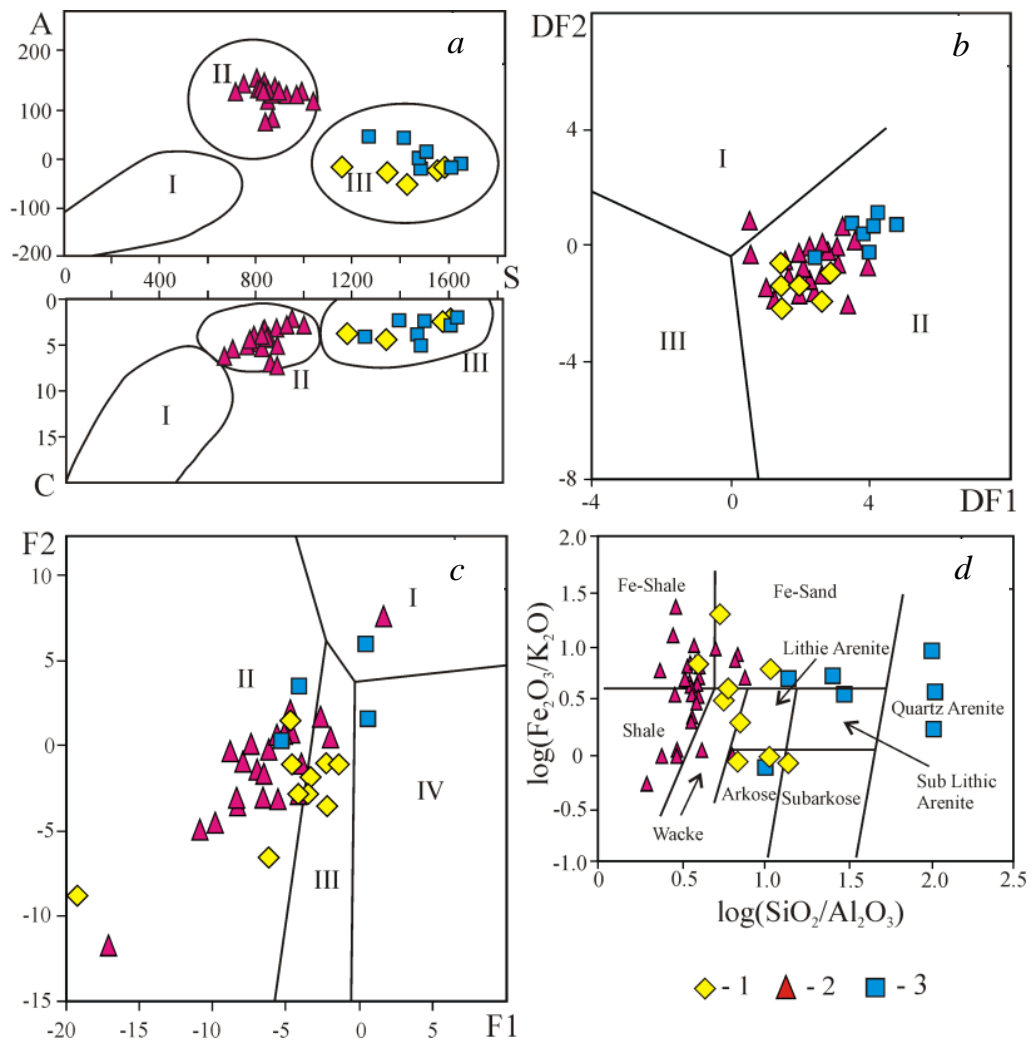

Fig. 5. Positions of the composition points of carbonaceous shales of the Sukharysh syncline on the standard classification diagrams. Sequences: 1 - Birgil'dinskaya, 2 - Tugundinskaya, 3 - Fedorovskaya. $a-\mathrm{A}-\mathrm{S}-\mathrm{C}$ classification diagram [11]. Fields of formations: I - carbonatecarbonaceous, II - terrigenous-carbonaceous, III - siliceous-carbonaceous. Parameters: A = $\left(\mathrm{Al}_{2} \mathrm{O}_{3}-\left(\mathrm{CaO}+\mathrm{K}_{2} \mathrm{O}+\mathrm{Na}_{2} \mathrm{O}\right)\right) \cdot 1000$ and $\mathrm{S}=\left(\mathrm{SiO}_{2}-\left(\mathrm{Al}_{2} \mathrm{O}_{3}+\mathrm{Fe}_{2} \mathrm{O}_{3}+\mathrm{FeO}+\mathrm{CaO}+\mathrm{MgO}\right)\right) \cdot 1000$ expressed in molecular amounts, parameter $\mathrm{C}=\mathrm{CaO}+\mathrm{MgO}$ expressed in weight percent of oxides. $b-\mathrm{DF} 1-\mathrm{DF} 2$ [12], where: $\mathrm{DF} 1=-0.263 \ln \left(\mathrm{TiO}_{2} / \mathrm{SiO}_{2}\right)_{\mathrm{adj}}+0.604 \ln \left(\mathrm{Al}_{2} \mathrm{O}_{3} / \mathrm{SiO}_{2}\right)_{\mathrm{adj}}$ $1.725 \ln \left(\mathrm{Fe}_{2} \mathrm{O}_{\text {зобш }} / \mathrm{SiO}_{2}\right)_{\text {adj }}+0.66 \ln \left(\mathrm{MnO} / \mathrm{SiO}_{2}\right)_{\mathrm{adj}}+2.191 \ln \left(\mathrm{MgO} / \mathrm{SiO}_{2}\right)_{\mathrm{adj}}+0.144 \ln (\mathrm{CaO} / \mathrm{SiO})_{\mathrm{adj}}$ $-1.304 \ln \left(\mathrm{Na}_{2} \mathrm{O} / \mathrm{SiO}_{2}\right)_{\mathrm{adj}}+0.054 \ln \left(\mathrm{K}_{2} \mathrm{O} / \mathrm{SiO}_{2}\right)_{\mathrm{adj}}-0.33 \ln \left(\mathrm{P}_{2} \mathrm{O}_{5} / \mathrm{SiO}_{2}\right)_{\mathrm{adj}}+1.588 ; \mathrm{DF} 2=$ 
$-1.196 \ln \left(\mathrm{TiO}_{2} / \mathrm{SiO}_{2}\right)_{\text {adj }}+\left[1.064 \ln \left(\mathrm{Al}_{2} \mathrm{O}_{3} / \mathrm{SiO}_{2}\right)_{\mathrm{adj}}+0.303 \ln \left(\mathrm{Fe}_{2} \mathrm{O}_{\text {зобщ }} / \mathrm{SiO}_{2}\right)_{\mathrm{adj}}+\right.$ $0.436 \ln \left(\mathrm{MnO} / \mathrm{SiO}_{2}\right)_{\mathrm{adj}}+0.838 \ln \left(\mathrm{MgO} / \mathrm{SiO}_{2}\right)_{\mathrm{adj}}-0.407 \ln \left(\mathrm{CaO} / \mathrm{SiO}_{2}\right)_{\mathrm{adj}}+1.021 \ln \left(\mathrm{Na}_{2} \mathrm{O} / \mathrm{SiO}_{2}\right)_{\mathrm{adj}}-$ $\left.1.706 \ln \left(\mathrm{K}_{2} \mathrm{O} / \mathrm{SiO}_{2}\right)_{\text {adj }}\right]-0.126 \ln \left(\mathrm{P}_{2} \mathrm{O}_{5} / \mathrm{SiO}_{2}\right)_{\text {adj }}-1.068$. The subscript "adj" indicates that the calculation is based on the oxide contents normalized to $100 \%$ dry matter. Fields of the sedimentation environments: I - island-arc, II - collision, III - rift-driven. $c-\mathrm{F} 1-\mathrm{F} 2$ [13], where: F1 = $30.638\left(\mathrm{TiO}_{2} / \mathrm{Al}_{2} \mathrm{O}_{3}\right)-12.541\left(\mathrm{Fe}_{2} \mathrm{O}_{3 \text { total }} / \mathrm{Al}_{2} \mathrm{O}_{3}\right)+7.329\left(\mathrm{MgO} / \mathrm{Al}_{2} \mathrm{O}_{3}\right)+12.031\left(\mathrm{Na}_{2} \mathrm{O} / \mathrm{Al}_{2} \mathrm{O}_{3}\right)+$ $35.402\left(\mathrm{~K}_{2} \mathrm{O} / \mathrm{Al}_{2} \mathrm{O}_{3}\right)-6.382, \mathrm{~F} 2=56.5\left(\mathrm{TiO}_{2} / \mathrm{Al}_{2} \mathrm{O}_{3}\right)-10.879\left(\mathrm{Fe}_{2} \mathrm{O}_{3 \text { total }} / \mathrm{Al}_{2} \mathrm{O}_{3}\right)+$ $30.875\left(\mathrm{MgO} / \mathrm{Al}_{2} \mathrm{O}_{3}\right)-5.404\left(\mathrm{Na}_{2} \mathrm{O} / \mathrm{Al}_{2} \mathrm{O}_{3}\right)+11.112\left(\mathrm{~K}_{2} \mathrm{O} / \mathrm{Al}_{2} \mathrm{O}_{3}\right)-3.89$. Fields of clastic material sources: I - sedimentary rocks rich in quartz, II - magmatic rocks of major element composition, III - magmatic rocks of average element composition, IV - magmatic rocks of acidic composition. $d-\log \left(\mathrm{SiO}_{2} / \mathrm{Al}_{2} \mathrm{O}_{3}\right)-\log \left(\mathrm{Fe}_{2} \mathrm{O}_{3 \text { total }} / \mathrm{K}_{2} \mathrm{O}\right)[14]$

On the $\log \left(\mathrm{SiO}_{2} / \mathrm{Al}_{2} \mathrm{O}_{3}\right)-\log \left(\mathrm{Fe}_{2} \mathrm{O}_{3} / \mathrm{K}_{2} \mathrm{O}\right)$ diagram [14] (Fig. 5, $d$ ), the imaging points of carbonaceous deposits of the Tugundinskaya sequence form a compact area in the fields of shales and ferruginous shales, while the deposits of the Birgil'dinskaya and Fedorovskaya sequences spread over the rest of the fields. Along with the changes in the chemical weathering index $\mathrm{CIA}=100 \mathrm{Al}_{2} \mathrm{O}_{3} /\left(\mathrm{Al}_{2} \mathrm{O}_{3}+\mathrm{CaO}+\mathrm{Na}_{2} \mathrm{O}+\mathrm{K}_{2} \mathrm{O}\right)$ [15], this testifies that the degree of sediment maturity increases consistently over the time interval.

\section{Conclusions}

The study of carbonaceous shales and aleurolites, which are widespread in the limestones of the Fedorovskaya sequence, leads to the following conclusions:

1. These deposits belong to the low-carbon type and fall into the field of the siliceous-carbonate unit.

2. The carbonaceous matter that developed in the form of scattered impurities and concentrated in the ultrafine veinlets and laminas corresponds to higher kerites subjected to catagenesis and the early stage of green shales facies.

3. Sedimentation occurred in the isolated local shallow-water depressions under the geodynamic conditions of collision. The terrigenous material was mainly formed as a result of the destruction of the underlying rocks of the major and average element composition of the Berezinskaya sequence. The maturity of the deposits consistently increases in time from the Tugundinskaya to Fedorovskaya sequences.

Acknowledgments. Thanks to R.R. Islamov and K.R. Nurieva for taking part in the fieldwork, E.O. Kalistratova for the help in description of the microsections of the samples, as well as T.I. Chernikova and S.A. Yagudin for their analytical research.

The study was performed as part of the State Assignment (project no. 0246-20190078).

\section{References}

1. Kissin A.Yu., Pritchin M.E. Fault tectonics of the Svetlinskoye gold deposit (South Urals) and its role in ore control. Vestn. Permsk. Univ. Geol., 2015, vol. 3, no. 28, pp 34-42. doi: 10.17072/psu.geol.28.34. (In Russian)

2. Snachev A., Snachev V. Gold bearing black shales of the Kamensk structure (Chelyabinsk graben, South Urals). Proc. Kazan Golovkinsky Stratigr. Meet., 2019: Sedimentary Earth Systems: Stratigraphy, Geochronology, Petroleum Resources (Kazan, Russian Federation, 24-28 Sept. 2019). Nurgaliev D., Alekseev A., Barclay M., Nikolaeva S., Silantiev V. (Eds.). Bologna, Italy, Filodiritto Publ., 2019, pp. 229-234. doi: 10.26352/D924F5039. 
3. Vikent'eva O., Prokofiev V., Borovikov A., Kryazhev S., Groznova E., Pritchin M., Vikentyev I., Bortnikov N. Contrasting fluids in the Svetlinsk gold-telluride hydrothermal system, South Urals. Minerals, 2019, vol. 10, no. 37, pp. 1-26. doi: 10.3390/min10010037.

4. Kolomoets A.V., Snachev A.V., Rassomakhin M.A. Gold-tourmaline mineralization in carbonaceous shales of the Kumak deposit (South Ural). Gorn. Zh., 2020, no. 12, pp. 11-15. doi: 10.17580/gzh.2020.12.02. (In Russian)

5. Snachev A.V., Kolomoets A.V., Rassomakhin M.A., Snachev V.I. Geology and gold content of carbonaceous shale in Baikal mineralization site, Southern Ural. Eurasian Min., 2021, no. 1, pp. 8-13. doi: 10.17580/em.2021.01.02.

6. Puzhakov B.A., Shokh V.D., Shchul'kina N.E., Shchul'kin E.P., Dolgova O.Ya., Orlov M.V., Popova T.A., Tarelkina E.A., Ivanov A.V. State Geological Map of the Russian Federation. Scale 1:200000. South Urals series. Sheet N-41-XIV (Troitsk). Explanatory letter. Moscow, VSEGEI, 2018. 238 p. (In Russian)

7. Yudovich Ya.E., Ketris M.P. Geokhimiya chernykh slantsev [Geochemistry of Black Shales]. Moscow, Berlin, Direkt-Media, 2015. 272 p. doi: 10.23681/428042. (In Russian)

8. Snachev A.V., Snachev V.I., Rykus M.V., Savelyev D.E., Bazhin E.A., Ardislamov F.R. Geologiya, petrogeokhimiya i rudonosnost' uglerodistykh otlozhenii Yuzhnogo Urala [Geology, Petrogeochemistry, and Ore Content of Carbonaceous Deposits of the South Urals]. Ufa, DizainPress, 2012. 208 p. (In Russian)

9. Ivanova V.P., Kasatov B.K., Krasavkina T.N., Rozinova E.L. Termicheskii analiz mineralov $i$ gornykh porod [Thermal Analysis of Minerals and Rocks]. Leningrad, Nedra, 1974. 399 p. (In Russian)

10. Silaev V.I., Men'shikova E.A., Kovaleva O.V., Petrovskii V.A., Sukharev A.E. Thermal stability of natural carbonaceous substances and their synthetic analogues. Problemy mineralogii, petrografii $i$ metallogenii: Materialy nauchnykh chtenii pamyati P.N. Chirvinskogo [Problems of Mineralogy, Petrography, and Metallogeny: Proc. Sci. Lect. in Memory of P.N. Chirvinsky]. Perm, Izd. PGU, 2009, no. 12, pp. 3-21. (In Russian)

11. Gorbachev O.V., Sozinov N.A. Some petrochemical and geochemical aspects for typification of the Precambrian carbonaceous deposits. In: Problemy osadochnoi geologil dokembriya [Problems of Precambrian Sedimentary Geology]. Moscow, Nauka, 1985, vol. 10, pp. 55-62. (In Russian)

12. Verma S.P., Armstrong-Altrin J.S. New multi-dimensional diagrams for tectonic discrimination of siliciclastic sediments and their application to Precambrian basins. Chem. Geol., 2013, vol. 355, pp. 117-133. doi: 10.1016/j.chemgeo.2013.07.014.

13. Roser B.P., Korsch R.J. Provenance signatures of sandstone-mudstone suites determined using discriminant function analysis of major-element data. Chem. Geol., 1988, vol. 67, nos.1-2, pp. 119-139. doi: 10.1016/0009-2541(88)90010-1.

14. Herron M.M. Geochemical classification of terrigenous sands and shales from core or log data. J. Sediment. Petrol., 1988, vol. 58, no. 5, pp. 820-829. doi: 10.1306/212F8E772B24-11D7-8648000102C1865D.

15. Nesbitt H.W., Young G.M. Early Proterozoic climates and plate motions inferred from major element chemistry of lutites. Nature, 1982, vol. 299, pp. 715-717. doi: 10.1038/299715a0.

Received

April 12, 2021

Snachev Alexander Vladimirovich, Candidate of Geological and Mineralogical Sciences, Head of the Ore Deposits Laboratory

Institute of Geology - Subdivision of the Ufa Federal Research Centre of the Russian Academy of Sciences

ul. Karla Marksa, 16/2, Ufa, 450077 Russia

E-mail: SAVant@rambler.ru 
ОРИГИнАЛЬНАЯ СТАТьЯ

УдК 551:551.735

doi: 10.26907/2542-064X.2021.2.264-273

\title{
Геология каменноугольных углеродистых отложений фёдоровской толщи Сухарышской синклинали (Южный Урал)
}

\section{A.B. Сначёв}

Институт геологии - обособленное структурное подразделение Федерального государственного бюджетного научного учреждения Уфимского федерального исследовательского иентра Российской академии наук, г. Уфа, 450077, Россия

\begin{abstract}
Аннотация
В статье рассмотрено геологическое строение каменноугольных отложений Сухарышской синклинали, расположенной в Копейско-Брединской подзоне Алапаевско-Адамовской структурноформационной зоны. Особое внимание уделено отложениям фёдоровской толщи $\left(\mathrm{C}_{2} \mathrm{fd}\right)$, выходы которых наблюдаются в разрезах вдоль реки Увельки и единичных придорожных карьерах. Мощность толщи порядка 1000 м, возраст отложений принят как средний карбон, башкирский век на основании определения многочисленной фауны. Показано, что сланцы и алевролиты, широко представленные среди известняков фёдоровской толщи, относятся к низкоуглеродистому типу и попадают в поле кремнисто-углеродистой формации. Углеродистое вещество, развитое в виде рассеянной примеси и концентрирующееся в тончайших прожилках и слойках, соответствует высшим керитам, подвергшимся катагенезу и начальной стадии фации зеленых сланцев. Содержания органического углерода достигают $2.8 \%$, что делает породу совершенно непрозрачной. Осадконакопление происходило в локальных изолированных мелководных впадинах в коллизионной геодинамической обстановке. Терригенный материал формировался преимущественно за счет разрушения нижележащих пород основного и среднего состава березиновской толщи, зрелость осадков последовательно увеличивается во времени от тугундинской к фёдоровской толще.
\end{abstract}

Ключевые слова: Южный Урал, Сухарышская синклиналь, фёдоровская толща, стратиграфия, палеогеография, углеродистые сланцы, черные сланцы, общий органический углерод, карбон

Поступила в редакцию 12.04.2021

Сначёв Александр Владимирович, кандидат геолого-минералогических наук, заведующий лабораторией «Рудных месторождений»

Институт геологии - обособленное структурное подразделение Федерального государственного бюджетного научного учреждения Уфимского федерального исследовательского центра Российской академии наук

ул. Карла Маркса, д. 16/2, г. Уфа, 450077, Россия

E-mail:SAVant@rambler.ru

For citation: Snachev A.V. The geology of carbonaceous deposits (carboniferous) of the South Urals (Fedorovskaya sequence, Sukharysh syncline). Uchenye Zapiski Kazanskogo Universiteta. Seriya Estestvennye Nauki, 2021, vol. 163, no. 2, pp. 264-273. doi: 10.26907/2542064X.2021.2.264-273.

/ Для цитирования: Snachev A.V. The geology of carbonaceous deposits (Carboniferous) of the South Urals (Fedorovskaya sequence, Sukharysh syncline) // Учен. зап. Казан. ун-та. Сер. Естеств. науки. - 2021. - Т. 163, кн. 2. - С. 264-273. - doi: 10.26907/2542064X.2021.2.264-273. 